\title{
Wzrost potęgi Chin i zmiana biegunowości w systemie międzynarodowym
}

\section{Wprowadzenie}

Po rozpadzie systemu bipolarnego i zakończeniu zimnej wojny jedynym supermocarstwem na świecie pozostały Stany Zjednoczone. Chińska Republika Ludowa była już wówczas mocarstwem nuklearnym i stałym członkiem Rady Bezpieczeństwa ONZ z prawem weta, ale potencjał gospodarczy i militarny był znacznie słabszy niż USA.

Zmiany w potencjałach państw zmieniają strukturę systemu międzynarodowego. Zwiększenie potęgi jednego z mocarstw zmniejsza względną przewagę dominującej jednostki. Efekty modernizacji Chin zapoczątkowanej ponad 40 lat temu, gospodarczy i technologiczny rozwój, a także coraz większa siła militarna Państwa Środka skłania do wysunięcia tezy, iż potęga ChRL znaczącą zwiększyła się w drugiej dekadzie XXI wieku, co nie pozostało bez wpływu na rozkład potęgi w systemie międzynarodowym.

Celem artykułu jest eksplanacja znaczenia wzrostu potęgi Chin w kontekście procesu zmiany biegunowości $\mathrm{w}$ systemie międzynarodowym, przede wszystkim poprzez analizę wskaźników ilościowych. W artykule przyjęto perspektywę paradygmatu realistycznego, ze szczególnym uwzględnieniem neorealizmu strukturalnego Kennetha Waltza. 


\section{Znaczenie paradygmatu realistycznego w badaniach nad potęgą państwa}

Potęga państwa (power) jest jedną z podstawowych kategorii badawczych nauki o stosunkach międzynarodowych. Kategoria ta określana jest w różnorodny sposób. Hans J. Morgenthau zaliczał do składników potęgi państwa geografię, zasoby naturalne, potencjał przemysłowy, gotowość bojową, ludność, charakter narodowy, morale narodowe, jakość dyplomacji, jakość rządu ${ }^{1}$. Odrzucając redukcjonizm klasycznego realizmu, „ojciec-założyciel” neorealizmu strukturalnego, Kenneth Waltz do potencjałów państwa zaliczał czynnik ekonomiczny, militarny i demograficzny, skupiając się jednak na tych dwóch pierwszych jako decydujących o obliczu systemu międzynarodowego ${ }^{2}$. John Mearsheimer uwzględnia w swych badaniach nad potęgą podobne wyznaczniki, analizując przede wszystkim sprzężenia występujące między potencjałem ekonomicznym a potencjałem militarnym mocarstw ${ }^{3}$. Na szczególny związek gospodarki i sił zbrojnych zwracał uwagę także Paul Kennedy ${ }^{4}$ Inni badacze stosunków międzynarodowych konstruowali bardziej lub mniej szerokie definicje potęgi państwa ${ }^{5}$. Powtarzalnymi elementami tych zestawień jest potencjał ekonomiczny i siła militarna. Realistyczny pogląd na potęgę uwzględnia zatem przede wszystkim jej materialny aspekt.

Dla Waltza od samej natury potęgi o wiele bardziej interesującym była zmiana w rozkładzie potencjałów w systemie międzynarodowym. Jak sam przyznawał, określenie liczby biegunów w systemie, a tym samym układu sił, nie jest sprawą najłatwiejszą ${ }^{6}$.

1 H. J. Morgenthau, Polityka między narodami. Walka o potęge i pokój, przejrzał i uzupełnił K. W. Thompson, wyd. skrócone, Warszawa 2010, s. 20-33.

2 K. Waltz, Struktura teorii stosunków międzynarodowych, Warszawa 2010, s. 21.

3 J. Mearsheimer, The Tragedy of Great Power Politics, Chicago 2014, s. 60-75.

4 Szerzej: P. Kennedy, Mocarstwa świata, Warszawa 1994.

5 Zob.: M. Sułek, Potęga państw. Modele i zastosowania, Warszawa 2013, s. 53-65;

D. Kondrakiewicz, Systemy równowagi sił w stosunkach międzynarodowych, Lublin 1999, s. 60-100.

6 K. Waltz, op. cit. 


\section{Rozwój potencjału gospodarczego i militarnego na tle innych mocarstw na początku XXI wieku}

Od lat 90. Stany Zjednoczone utrzymywały względną przewagę w sferze ekonomicznej, technologicznej i militarnej. Wydawało się, że nowa „liberalna hegemonia" USA trwale ukształtuje porządek światowy ${ }^{7}$. Jednak początek XXI wieku przyniósł gwałtowne turbulencje w systemie międzynarodowym. Wydarzenia z 11 września 2001 roku wstrząsnęły światem i postawiły przed globalnymi potęgami nowe wyzwania. „Wojna $z$ terroryzmem” przyniosła istotne implikacje dla międzynarodowej polityki. Potęga USA - jedynego supermocarstwa - została geostrategicznie rozciągnięta, a jednoczesne zaangażowanie militarne w Afganistanie i Iraku zmniejszyły amerykański potencjał. Stany Zjednoczone poniosły ogromne koszty, obok nieprzeliczalnych na pieniądze strat ludzkich, wydatki budżetowe na prowadzenie operacji w Afganistanie i Iraku w latach 2001-2015 miały wynieść (według ocen z 2013 roku) 1,6 mld USD $^{8}$. Kryzys finansowy, który w USA wybuchł w 2008 roku, pogłębił trudną sytuację amerykańskiej gospodarki. W 2008 i 2009 roku Stany Zjednoczone miały ujemny wzrost gospodarczy na poziomie odpowiednio $-0,3 \mathrm{i}-2,8 \%$. Japonia w 2008 roku miała ujemny wzrost gospodarczy w wysokości 1\%, ale w 2010 roku wyniósł on już $-5,5 \%$. Brazylia tylko w 2009 roku zanotowała $-0,1 \%$ przyrostu PKB (chociaż spadek był drastyczny - z 5,1\% w 2008 roku, odbicie jeszcze bardziej imponujące $-7,5 \%$ w 2010 roku). Indie notowały nieprzerwany wzrost PKB w wysokości 3,9\% w 2008 roku i 8,5\% w 2009 roku. Rosja miała ujemny wzrost gospodarczy jedynie w 2009 roku, który wyniósł aż $-7,8 \%$. Gospodarka Chin nadal rosła w imponującym tempie, wzrost wyniósł odpowiednio 9,6\% oraz 9,2\% w 2008 i 2009 roku'. Dług publiczny netto Stanów Zjednoczonych w 2009 roku wyniósł 53,8\% rocznego PKB. Natomiast rezerwy finansowe Brazylii wzrosły w tym samym roku do 238,4 mld USD, Chin - do 2343,5 mld, Indii - do 268,2 mld, a Rosji - 424,6 mld $^{10}$.

7 J. Ikenberry, Liberal hegemony and the future of the American postwar order, [w:] International Order and the Future of World Politics, t. V. Paul, J. A. Hall (red.), New York 1999, s. 123-145.

8 A. Belasco, The Cost of Iraq, Afghanistan, and Global War on Terror Operations Since 9/11, 29.03.2011, „CRS Report for Congress”, s. 6, http://www.fas.org/sgp/crs/natsec/ RL33110.pdf (dostęp: 04.05.2016).

9 GDP growth (annual \%), http://data.worldbank.org/indicator/NY.GDP.MKTP.KD. ZG?page=1 (dostęp: 06.05.2016).

10 World Economic Outlook. Rebalancing Growth. April 2010, International Monetary Fund, Washington D.C. 2011, s. 155-182. 
Na koniec września 2013 roku chińskie rezerwy finansowe wyniosły już 3,66 biliona USD ${ }^{11}$.

Rok 2015 przyniósł zmianę w trendach makroekonomicznych. Japonia osiągnęła niewielki wzrost 0,5\%, PKB Rosji spadło o 3,7\%, Brazylii o 3,8\%, natomiast Indii wzrosło aż o 7,4\%. Wzrost PKB Chin wyniósł 6,9\%, z kolei Stany Zjednoczone odnotowały w 2015 roku wzrost PKB w wysokości $2,45 \%{ }^{12}$.

Spadek przyrostu PKB skutkował mniejszymi dochodami dla budżetu państw. Wydatki rządowe były poddawane rozmaitym cięciom; w większości przypadków jako jedne z pierwszych zmniejszane były nakłady na siły zbrojne. Dotyczyło to przede wszystkim programów zbrojeniowych. Taka sytuacja miała jednak miejsce głównie w krajach demokratycznych. W latach 2013-2015 budżet Departamentu Obrony spadał, by dopiero w roku budżetowym 2016 osiągnąć 521,7 mld USD na poziomie bazowym (ogół wydatków na cele militarne określono na 773,5 mld USD) i stał się wyższy niż w 2013 roku (chociaż niższy niż w 2012 roku) ${ }^{13}$. Według Stockholm International Peace Research Institute (SIPRI), budżet obrony USA wyniósł (w cenach bieżących) w 2015 roku 596 mld USD, Chin - 214,787 mld USD, Rosji - 66,421 mld USD, Indii - 51,257 mld USD, Japonii - 40,885 USD, a Brazylii 24,584 mld USD ${ }^{14}$. Budżet obrony Brazylii został zredukowany o $25 \%$ z powodu trudności finansowych kraju i ujemnego wzrostu gospodarczego, obcięte zostały zwłaszcza wydatki na zaopatrzenie, $w$ tym na nowe programy zbrojeniowe, które ograniczono o 3 mld USD ${ }^{15}$.

Budżet obronny Chin trudno precyzyjnie określić. Jak zauważają Adam Liff i Andrew Erickson, wydatki na cele wojskowe w ChRL w latach 20022011 oficjalnie nie przekroczyły $1,5 \%{ }^{16}$. Tymczasem według zestawień SIPRI

11 Dane Ludowego Banku Chin, za: China's Biggest Reserves Jump Since 2011 Shows Inflow, „Bloomberg News”, 15.10.2015, http://www.bloomberg.com/news/2013-10-14/ china-s-biggest-reserves-jump-since-2011-shows-inflow.html (dostęp: 05.05.2016).

12 World Economic Outlook. Too Slow for Too Long, International Monetary Fund, Washington D.C. 2016, s. 170-173.

13 K. Amadeo, U.S. Military Budget: Components, Challenges, Growth, „About Money”, 23.02.2016, http://useconomy.about.com/od/usfederalbudget/p/military_budget.htm (dostęp: 26.05.2016).

14 Dane wygenerowane z SIPRI Military Expenditure Database, Stockholm International Peace Research Institute, http://www.sipri.org/research/armaments/milex/milex_database/milex_database (dostęp: 26.05.2016).

15 I. Guevara, Brazil's defense procurement budget cut by 25\%, http://www.janes.com/article/51692/brazil-s-2015-defence-procurement-budget-cut-by-25 (dostęp: 26.05.2016).

16 A. Liff, A. Erickson, Demystifying China's Defense Spending: Less Mysterious in the Aggregate, „The China Quarterly” 2013, nr 216, s. 4-6. 
kształtowały się $\mathrm{w}$ wymienionym okresie na poziomie $1,9-2,2 \% \mathrm{PKB}$, od 2010 do 2015 roku przyjmując 1,9\% PKB. Było to jednocześnie w latach 2008-2015 od 6,3\% do 8,38\% wszystkich wydatków rządowych. Dla porównania, w tym samym czasie Stany Zjednoczone - obarczone wciąż misjami w Iraku i Afganistanie - przeznaczały na budżet obronny od 3,3\% do 4,7\% PKB i od 9,2\% do $11,9 \%$ wydatków rządowych, a Rosja od 3,3\% do 5,4\% PKB, co stanowiło aż od 9,9\% do 13,7\% wszystkich wydatków rządowych ${ }^{17}$.

Dodatkowo ocenę rzeczywistych nakładów na cele wojskowe w ChRL utrudniają jeszcze trzy kwestie. Po pierwsze, różnice $w$ danych wynikają przede wszystkim ze sposobu przeliczania podawanych oficjalnie kwot przez ChRL na dolary USA, różne liczby pojawiają się w zależności od przyjęcia „nominalnych” (w cenach bieżących) albo „realnych” (w cenach stałych) wartości wydatków. Po drugie, chińskie informacje na temat wydatków na obronę są jeszcze mniej transparentne niż w innych krajach, a przez to mniej wiarygodne ${ }^{18}$. Wreszcie, niektórzy badacze zwracają uwagę, że do budżetu nie są wliczane nakłady przeznaczane na utrzymanie liczącej 600 tys. ludzi Zbrojnej Policji Ludowej, sumy alokowane na B+R prowadzone przez instytucje naukowo-badawcze oraz wydatki na uzbrojenie zakupione zagranicą albo szczególnie kosztowny sprzęt wojskowy wyprodukowany w kraju ${ }^{19}$.

W 2015 roku budżet na cele obronne ChRL wyniósł oficjalnie 886,9 mld yuanów (RMB), czyli około 144,2 mld USD, i wzrósł 10,1\% w porównaniu $\mathrm{z}$ rokiem poprzednim ${ }^{20}$. Przyrost wydatków na cele militarne był większy niż wzrost chińskiego PKB, który ukształtował się na poziomie $6,9 \%{ }^{21}$. Według szacunków SIPRI Chiny przeznaczyły na obronę w tym samym roku 214.787 mld USD, natomiast dla Stanów Zjednoczonych i Rosji podano wskaźniki podobne do danych oficjalnych tych państw - odpowiednio około 596 mld USD i 66,421 mld USD ${ }^{22}$. W przypadku Chin była to kwota większa o 70 mld USD, a więc prawie $50 \%$.

17 SIPRI Military Expenditure...

18 Por: R. Kwieciński, Zmiana w systemie międzynarodowym a pozycja Chińskiej Republiki Ludowej na początku XXI w., „Gentes \& Nationes” 2013, nr 8, s. 37.

19 A. Liff, A. Erickson, op. cit., s. 7.

20 China 2015 defense budget to grow 10,1 pct, lowest in 5 years, „Xinhua”, 05.03.2015, http://news.xinhuanet.com/english/2015-03/05/c_134038801.htm (dostęp: 28.05.2016).

21 M. Magnier, Chinas Economic Growth in 2015 Is Slowest in 25 Years, „Wall Street Journal”, 11.01.2016, http://www.wsj.com/articles/china-economic-growth-slowsto-6-9-on-year-in-2015-1453169398 (dostęp: 28.05.2016).

22 SIPRI Military Expenditure... 
Fareed Zakaria, rozróżniając „siłę państwa” i „siłę narodu”, definiuje tę pierwszą jako umiejętność skutecznego ukierunkowania bogactwa i mobilizacji społecznej ${ }^{23}$. W systemach autorytarnych o wiele łatwiej jest dokonać mobilizacji społeczeństwa, a przede wszystkim zadecydować o kierunkach wydatków państwowych.

Chińska Republika Ludowa jest państwem autorytarnym, w którym redystrybucja bogactwa odbywa się pod kontrolą aparatu państwowego i KPCh. Ułatwia to skierowanie posiadanych zasobów do realizacji założonych celów, zarówno siły żywej, jak i środków budżetowych. Sukces gospodarczy Chin w ostatnich dwudziestu pięciu latach spowodował, że możliwości państwa w zakresie finansowania reformy wojska systematycznie wzrastają.

Obecnie najpotężniejszą siłą militarną na świecie jest armia Stanów Zjednoczonych, która nie jest możliwa do zrównoważenia w konwencjonalny sposób przez jakiekolwiek państwo albo sojusz państw. Jednak zwiększający się potencjał Chińskiej Armii Ludowo-Wyzwoleńczej (ChAL-W) sprawia, że jej możliwości konsekwentnie rosną. Podejmując wysiłek modernizacji armii, Chiny jako punkt wyjścia przyjęły efekt „Rewolucji w sprawach wojskowych” („Revolution in Millitary Affairs” - RMA), która pojawiła się wraz z błyskawicznym zwycięstwem wojsk amerykańskich podczas I wojny w Zatoce Perskiej. Szczególną uwagę zwrócono na rozwój lotnictwa, systemów dowodzenia, kontroli, komunikacji, technologii informatycznych, obserwacji, wywiadu rozpoznania („Command, Controls, Communication, Computers, Surveillance, Intelligence, Reconaissance" - C4SIR), mechanizacji armii, rozwoju wojsk rakietowych, jak również stworzenia nowoczesnych formacji szybkiego reagowania. Natomiast rezultatem napięć w Cieśninie Tajwańskiej w latach 90. i na początku XXI wieku, konieczności ochrony morskich szlaków komunikacyjnych („Sea Lines of Communications” - SLOC), a także sporów terytorialnych na Morzu Południowochińskim i Morzu Wschodniochińskim było wprowadzenie w życie przez Chiny znaczącego programu morskiego.

Konsekwencją tych działań było posiadanie przez Chiny na koniec 2015 roku, według analityków amerykańskich przygotowujących coroczne opracowania dla Kongresu USA, 56 okrętów podwodnych, z tego 41 nowoczesnych. Na 56 okrętów podwodnych było tylko 7 okrętów o napędzie atomowym, z czego 4 przenoszące rakiety balistyczne z głowicami jądrowymi (SSBN), a 3 przeznaczone do zwalczania okrętów nawodnych przeciwnika

23 F. Zakaria, From Wealth to Power: the Unusual Origins of America's World Power, Princeton 1998, s. 39, 101. 
$(\mathrm{SSN})^{24}$. Zdaniem amerykańskiego wiceadmirała Josepha Mulloyoa, w lutym 2015 roku Chiny posiadały więcej okrętów podwodnych o napędzie konwencjonalnym niż Stany Zjednoczone, chociaż o znacznie mniejszych zdolnościach bojowych niż okręty amerykańskie ${ }^{25}$.

Na koniec 2015 roku Chiny posiadały wciąż jeden konwencjonalny lotniskowiec, który jest dokończoną konstrukcją poradziecką, o skromnych możliwościach bojowych. Trwają jednak intensywne prace nad budową pierwszego rodzimego lotniskowca, także o napędzie konwencjonalnym ${ }^{26}$. Być może w najbliższych latach Chiny będą dysponowały już 3 lotniskowca$\mathrm{mi}$, w tym obecnie posiadanym Laoningiem. Flotę nawodną tworzy również 22 niszczycieli i 35 fregat, które w większości można uznać za nowoczesne, a także 3 duże okręty amfibijne. Całość uzupełniają liczne korwety i pełnomorskie okręty patrolowe ${ }^{27}$. Największe zagrożenie dla okrętów amerykańskich mogą jednak stanowić przeciwokrętowe rakiety balistyczne (Anti-Ships Ballistic Missile) wystrzeliwane $\mathrm{z}$ lądu.

\section{Trendy i prognozy wzrostu potęgi Chin}

Dane makroekonomiczne chińskiej gospodarki z ostatniego ćwierćwiecza potwierdzają sukces, jaki odniósł program „Czterech Modernizacji”. Rozwój gospodarczy Chin przez ponad ćwierćwiecze opierał się przede wszystkim na dwóch składnikach produktu krajowego brutto: inwestycjach i dodatnim saldzie $\mathrm{w}$ handlu zagranicznym. Inwestycje tworzyły nowe miejsca pracy oraz rozwijały infrastrukturę, także tę niezbędną dla biznesu. Stosunkowo duży eksport podyktowany był przede wszystkim wciąż niską konsumpcją wewnętrzną, która skłaniała chińskie przedsiębiorstwa do ekspansji na rynkach zagranicznych. Wysoki wzrost $\mathrm{PKB}$ powiększał rezerwy finansowe ChRL, ale przede wszystkim sprawiał, że do dyspozycji rządzących było coraz więcej środków.

Zgodnie z proponowanym przez Edwarda Haliżaka „paradygmatem modernizacyjnym" najważniejszym celem chińskich elit politycznych jest

24 R. O'Rourke, China Naval Modernization: Implications for U.S. Navy Capabilities - Background and Issues for Congress, Washington D.C. 2016, s. 16.

25 China submarines outnumber U.S. fleet: U.S. admiral, „Reuters”, 25.02.2015, http:// www.reuters.com/article/us-usa-china-submarines-idUSKBN0LT2NE20150225 (dostęp: 29.05.2016).

26 R. O'Rourke, op. cit., s. 18-21.

27 Ibidem, s. 27-38. 
kontynuacja reform zapoczątkowanych w 1978 roku $^{28}$. Jego realizacja zakłada sprostanie wyzwaniom społeczno-ekonomicznym, jakie stoją przed krajem i które nakreślił jeszcze premier Wen Jiabao: niska konsumpcja, nadmierny wzrost stóp inwestycji, kredytów, niezbalansowany rozwój miast i wsi, Wschodu i Zachodu państwa, zależność od inwestycji i eksportu, brak sukcesów w oszczędzaniu energii, redukcji emisji zanieczyszczeń oraz ochronie środowiska ${ }^{29}$. Odpowiedź na te wyzwania ma zapewnić powstanie państwa o „ograniczonym dobrobycie” oraz realizację oczekiwań chińskiego społeczeństwa, które Xi Jinping, obecny przewodniczący ChRL, zidentyfikował obejmując władzę w 2012 roku jako pragnienie „lepszego wykształcenia, bardziej stabilnej pracy, lepszych podatków, bardziej niezawodnych ubezpieczeń społecznych, opieki społecznej o wysokim standardzie, wygodniejszego życia i piękniejszego środowiska naturalnego" 30 .

Chińskie przemiany wpływają na zwiększenie wartości wyznaczników materialnej potęgi ChRL, ale zmieniają także mniej tradycyjne wskaźniki. Autorzy „Global Trends 2030: Alternative Worlds” z amerykańskiej National Intelligence Council przedstawiają prognozę rozwoju siły największych mocarstw współczesnego świata stosując dwie definicje potęgi. W tradycyjnej formule uwzględniają PKB, wielkość populacji, wydatki wojskowe i technologię. W bardziej nowoczesnym ujęciu uwzględniają jeszcze edukację, ochronę zdrowia i sposób rządzenia (governance). W analizie, w której zastosowano bardziej tradycyjną definicję, Chiny zrównoważą potęgę USA około 2030 roku. Stosując szerszą definicję potęgi, która uwzględnia nowe czynniki, zrównoważenie potęgi Stanów Zjednoczonych nastąpi między 2040 a 2045 roku. W obu przypadkach, po zrównoważeniu amerykańskiej potęgi, utrzymać się ma rosnący trend dla potęgi ChRL i malejący dla USA ${ }^{31}$.

Credit Suisse Research w publikacji „The End of Globalization or a More Multipolar World” z września 2015 roku, bierze pod uwagę przede wszystkim wartość PKB (uzupełnioną kilkoma czynnikami korygującymi) i to

28 E. Haliżak, Zmiana układu sił USA - Chiny a transformacja porządku międzynarodowego, seria: „Żurawia Papers”, zeszyt 7, Warszawa 2005, s. 29.

29 Premier: China confident in maintaining economic growth, „Xinhua”, 16.03.2007, http:// news.xinhuanet.com/english/2007-03/16/content_5856569.htm (dostęp: 28.05.2016).

30 Council on Foreign Relations, Xi Jinping's Speech After Appointment to Leadership, November 2012, http://www.cfrokuorg/china/xi-jinpings-speech-after-appointment-leadership-november-2012/p29479 (dostęp: 28.05.2015).

31 Global Trends 2030: Alternative Worlds, National Intelligence Council, Washington D.C. 2012 , s. 17. 
w Parytecie Siły Nabywczej. W takim ujęciu, potęga Stanów Zjednoczonych została już zrównoważona na jesieni 2014 roku Zdaniem autorów, multipolarny świat, w którym punkt ciężkości przesunie się do Azji przewodzonej przez Chiny, może oznaczać koniec globalizacji ${ }^{32}$.

Mirosław Sułek rozróżnia potęgę ogólną oraz potęgę militarną państwa. Potęga ogólna jest iloczynem wartości PKB, liczby ludności i powierzchni terytorium kraju opatrzonych wykładnikami potęgowymi. Natomiast potęga militarna ma formułę iloczynu wydatków na cele wojskowe, liczby żołnierzy i terytorium państwa $\mathrm{z}$ uwzględnieniem takich samych wykładników potęgowych ${ }^{33}$. Wyniki tych formuł w odniesieniu do całości potęgi globalnej (o wartości 1000) określone zostały jako „milimiry” (mM).

Zgodnie z takim podejściem potęga ogólna USA w 2011 roku to 13,95\% potęgi świata, a Chiny posiadają jej $11,90 \%{ }^{34}$. Po niewielkim przekształceniu, przyjmując wartości $\mathrm{mM}$, potęga ogólna Stanów Zjednoczonych w 2013 roku była wciąż największa na świecie i wynosiła 143,58 mM, natomiast potęga Chin była druga - 133,67 mM, Indie trzecie - 40,999 mM, Japonia czwarta - 37,087 mM, Brazylia piąta - 34,747 mM, a Rosja dopiero szósta - 33,22 $\mathrm{mM}^{35}$. Natomiast w przypadku potęgi militarnej, Stany Zjednoczone zajęły w 2013 roku pierwsze miejsce z wartością 227,951 mM, drugie miejsce przypadło Chinom - 84,488 mM, a trzecie Rosji - 52,103 mM ${ }^{36}$. Reinterpretując wyniki uzyskane na podstawie formuły M. Sułka, w 2013 roku USA posiadały ponad $22 \%$ światowej potęgi militarnej.

Zgodnie z modelem M. Sułka, potęga ogólna Chin jest zatem dość blisko potęgi ogólnej Stanów Zjednoczonych. Jednak potęga militarna Chin jest trzykrotnie mniejsza, co zdaje się odpowiadać rzeczywistości.

32 The End of Globalization or a More Multipolar World?, Credit Suisse Research, Zurich 2015, s. 6-7.

$33 \mathrm{P}_{\mathrm{o}}=\mathrm{D}^{0,652} \times \mathrm{L} 0,217 \times \mathrm{p} 0,109$, gdzie $\mathrm{P}_{\mathrm{o}}$, to potęga ogólna państwa. L to całkowita liczba ludności, a p - powierzchnia państwa. Natomiast wzór na potęgę militarną definiuje jako wynik działania $\mathrm{P}_{\mathrm{m}}=\mathrm{W}^{0,652} \times \mathrm{S}^{0,217} \times \mathrm{p}^{0,109}$, gdzie Pm to potęga militarna, W - wydatki na cele wojskowe, S - liczba żołnierzy w służbie czynnej, a p - powierzchnia państwa. M. Sułek, op. cit., s. 179.

34 Ibidem, s. 301.

35 M. Sułek (red.), Potęga 2015, Kraków 2015, s. 26.

36 Ibidem, s. 34. 


\section{Podsumowanie}

Właściwe podsumowanie tego tematu może odbyć się tylko przy zastrzeżeniu, że przedstawiane trendy zostały właściwie odczytane i utrzymają się w nadchodzącej, przewidywalnej przyszłości.

Utrzymanie trendów wzrostu gospodarczego Chin prawdopodobnie przyniesie sytuację, w której potęga ogólna ChRL przewyższy potęgę ogólną USA. Duża część dotychczasowych prognoz określała w przybliżeniu datę tego wydarzenia jako lata 30.-40. tego wieku. Jednak wysoki wzrost chińskiej gospodarki (blisko albo ponad 10\% PKB) należy dzisiaj do przeszłości. Zmniejszenie poziomu inwestycji i gorsze wyniki w handlu zagranicznym mogą oznaczać korektę trendu. Struktura chińskiego PKB przechodzi obecnie transformację, ale poziom konsumpcji wewnętrznej wciąż jest zbyt niski. Dodatkowo, gospodarka amerykańska wróciła na ścieżkę wzrostu. Może to oznaczać oddalenie momentu, w którym chińskie PKB w cenach realnych będzie większe niż PKB Stanów Zjednoczonych.

Ale nawet wówczas - jak należy sądzić - potęga militarna USA może nie zostać zrównoważona. Obecnie amerykańska siła militarna, wg formuły M. Sułka, jest prawie trzykrotnie większa niż chińska. Utrzymanie względnej przewagi militarnej przez Stany Zjednoczone mogłoby zapewnić temu mocarstwu odgrywanie nadal decydującej roli w systemie międzynarodowym. Tym bardziej, że reszta kandydatów do miana kolejnych biegunów w świecie multipolarnym (Brazylia, Indie, Japonia, Rosja, a także być może jednak Unia Europejska) zmaga się z problemami wzrostu ekonomicznego, słabym przyrostem naturalnym, brakiem wystarczającej koordynacji politycznej, czy trudnościami w określeniu własnej roli w systemie międzynarodowym.

Świat zatem będzie zmierzał do stanu, w którym będą dwa mocarstwa przewyższające potencjałami pozostałe mniejsze bieguny. Brak dwóch rywalizujących ze sobą bloków skłania do wykluczenia ścisłej bipolarności przyszłego systemu międzynarodowego. Jednak przewaga potencjału ogólnego Stanów Zjednoczonych i Chin nad pozostałymi biegunami wyklucza też ścisły multipolaryzm. Czeka nas więc nowy układ, którego jeszcze dotąd nie doświadczyliśmy. Nowy świat na miarę nowych czasów.

\section{Bibliografia}

AMADEO K., U.S. Military Budget: Components, Challenges, Growth, „About Money", 23.02.2016, http://useconomy.about.com/od/usfederalbudget/p/military_budget.htm. 
BELASCO A., The Cost of Iraq, Afghanistan, and Global War on Terror Operations Since 9/11, „CRS Report for Congress”, 29.03.2011, http://www.fas. org/sgp/crs/natsec/RL33110.pdf

CHINA 2015 defense budget to grow 10,1 pct, lowest in 5 years, „Xinhua”, 05.03.2015, http://news.xinhuanet.com/english/2015-03/05/c_134038801.htm.

CHINA submarines outnumber U.S. fleet: U.S. admiral, „Reuters”, 25.02.2005, http://www.reuters.com/article/us-usa-china-submarines-dUSKBNOLT2NE20150225.

CHINA'S Biggest Reserves Jump Since 2011 Shows Inflow, „Bloomberg News”, http://www.bloomberg.com/news/2013-10-14/china-s-biggest-reservesjump-since-2011-shows-inflow.html.

COUNCIL on Foreign Relations, Xi Jinping's Speech After Appointment to Leadership, November 2012, http://www.cfr.org/china/xi-jinpings-speech -after-appointment-leadership-november-2012/p29479.

THE End of Globalization Or a More Multipolar World?, Credit Suisse Research, Zurich 2015.

GLOBAL Trends 2030: Alternative Worlds, National Intelligence Council, Washington D.C. 2012.

GUEVARA I., Brazil's defence procurement budget cut by 25, http://www.janes.com/article/51692/brazil-s-2015-defence-procurement-budget-cutby- 25 .

HALIŻAK E., Zmiana układu sił USA - Chiny a transformacja porządku międzynarodowego, seria: „Żurawia Papers”, zeszyt 7, Warszawa 2005.

KONDRAKIEWICZ D., Systemy równowagi sił w stosunkach międzynarodowych, Lublin 1999.

KWIECIŃSKI R., Zmiana w systemie międzynarodowym a pozycja Chińskiej Republiki Ludowej na początku XXI w., „Gentes \& Nationes” 2013, nr 8.

LIFF A., ERICKSON A., Demystifying China's Defense Spending: Less Mysterious in the Aggregate, „The China Quarterly” 2013, nr 216.

MAGNIER M., Chinas Economic Growth in 2015 Is Slowest in 25 Years, „Wall Street Journal", http://www.wsj.com/articles/china-economic-growth-slows -to-6-9-on-year-in-2015-1453169398.

MEARSHEIMER J., The Tragedy of Great Power Politics, Chicago 2014.

MORGENTHAU H. J., Polityka między narodami. Walka o potęge i pokój, przejrzał i uzupełnił K. W. Thompson, wyd. skrócone, Warszawa 2010.

O'ROURKE R., China Naval Modernization: Implications for U.S. Navy Capabilities - Background and Issues for Congress, Washington D.C. 2016.

PREMIER: China confident in maintainingeconomic growth, „Xinhua”, 16.03.2007, http://news.xinhuanet.com/english/2007-03/16/content_5856569.htm. 
SIPRI Military Expenditure Database, Stockholm International Peace Research Institute, http://www.sipri.org/research/armaments/milex/milex_ database/milex_database.

SUŁEK M., Potęga państw. Modele i zastosowania, Warszawa 2013.

SUŁEK M. (red.), Potega 2015, Kraków 2015.

WALTZ K., Struktura teorii stosunków międzynarodowych, Warszawa 2010.

WORLD Economic Outlook. Too Slow for Too Long, International Monetary Fund, Washington D.C. 2016.

ZAKARIA F., From Wealth to Power: the Unusual Origins of America's World Power, Princeton 1998. 